\title{
Solanum americanum: reservoir for Potato virus $Y$ and $C$ Cucumber mosaic virus in sweet pepper crops
}

\author{
Monika Fecury Moura, Marcelo Soman, Tatiana Mituti, Marcelo Agenor Pavan, Renate Krause-Sakate
}

Faculdade de Ciências Agronômicas, FCA-UNESP, Departamento Proteção Vegetal, Rua José Barbosa de Barros, 1780, CEP: 18610-307, Botucatu, SP, Brazil.

Autor para correspondência: Renate Krause-Sakate (renatekrause@fca.unesp.br)

Data de chegada: 25/06/2013. Aceito para publicação em: 10/02/2014.

1901

\section{ABSTRACT}

Moura, M. F.; Soman, M.; Mituti, T.; Pavan, M. A.; Krause-Sakate, R. Solanum americanum: reservoir for Potato virus Y and Cucumber mosaic virus in sweet pepper crops. Summa Phytopathologica, v.40, n.1, p.78-80, 2014.

Weeds can act as important reservoirs for viruses. Solanum americanum (Black nightshade) is a common weed in Brazil and samples showing mosaic were collected from sweet pepper crops to verify the presence of viruses. One sample showed mixed infection between Cucumber mosaic virus (CMV) and Potato virus $Y(\mathrm{PVY})$ and one sample showed simple infection by PVY. Both virus species were transmitted by plant extract and caused mosaic in tomato
(Solanum lycopersicum cv. Santa Clara), sweet pepper (Capsicum annuиm cv. Magda), Nicotiana benthamiana and N. tabaccum TNN, and local lesions on Chenopodium quinoa, C. murale and C. amaranticolor. The coat protein sequences for CMV and PVY found in S. americanum are phylogenetically more related to isolates from tomato. We conclude that $S$. americanum can act as a reservoir for different viruses during and between sweet pepper crop seasons.

Additional keywords: Weeds, Cucumovirus, Potyvirus

\section{RESUMO}

Moura, M. F.; Soman, M.; Mituti, T.; Pavan, M. A.; Krause-Sakate, R. Solanum americanum: reservatório de Potato virus Y e Cucumber mosaic virus em áreas de cultivo de pimentão. Summa Phytopathologica, v.40, n.1, p.78-80, 2014.

As plantas daninhas podem atuar como importantes reservatórios de vírus. Solanum americanum (Maria Pretinha) é uma planta daninha comum no Brasil e amostras com mosaico foram coletadas em áreas produtoras de pimentão, para verificar a presença de vírus. Uma amostra apresentou infecção mista com Cucumber mosaic virus (CMV) e Potato virus Y (PVY) e uma amostra apresentou infecção simples com PVY. As duas espécies virais foram transmitidas por extrato vegetal e ocasionaram mosaico em tomate (Solanum lycopersicum cv. Santa Clara), pimentão (Capsicum annuum cv. Magda), Nicotiana benthamiana e N. tabaccum TNN, lesões locais em Chenopodium quinoa, C. murale e C. amaranticolor. As sequências de proteína capsidial para o CMV e PVY encontradas em S. americanum estão filogeneticamente mais relacionadas com isolados de tomate. Conclui-se que $S$. americanum pode atuar como reservatório de diferentes vírus, durante e entre as épocas de cultivo de pimentão.

Palavras-chave adicionais: plantas daninhas, Cucumovirus, Potyvirus

Solanum americanum Mill. (black nightshade) is an annual plant classified into the family Solanaceae. In Brazil, this species is commonly found in tomato and pepper crops. Species of begomoviruses (1), tospoviruses (8), Potato virus Y (PVY) (5) and Cucumber mosaic virus (CMV) (9) have already been reported for that host.

S. americanum plants showing mosaic symptoms and leaf distortion were found naturally occurring in sweet pepper crops in São Paulo State (Lins region, October 2011) and the presence of viruses was investigated (Figure 1).

Double-antibody sandwich (DAS)-ELISA was carried out for the presence of potyvirus genus by utilizing antiserum anti-potyvirus (Agdia Inc., Elkhart, IN) (11). Two potyvirus positive samples (71d and $72 d$ ) were also analyzed by leaf dip, using Uranyl acetate (3\%) as contrast solution, under an electron microscope (CM100 - Phillips), and $800 \mathrm{~nm}$ filamentous particles, of potyvirus type, were observed for both samples. Presumed isometric particles were observed on sample $72 \mathrm{~d}$.

For the biological tests, sap from the leaf samples $71 \mathrm{~d}$ and $72 \mathrm{~d}$ was prepared in $0.02 \mathrm{M}$ phosphate buffer, $\mathrm{pH} 7.0$, carborundum as abrasive, and inoculated into Nicotiana tabaccum L. "TNN", $N$. benthamiana Domin, Chenopodium quinoa Willd., C. amaranticolor Coste and Reyn, C. murale L., Capsicum annuum L. cv. Magda and Solanum lycopersicum Mill cv. Santa Clara. Mottle on C. annuum, $N$. benthamiana, N. tabaccum cv. TNN and S. lycopersicum, and local lesions on C. quinoa, C. murale and C. amaranticolor were observed for samples $71 \mathrm{~d}$ and $72 \mathrm{~d}$.

Total RNA was extracted from the original plants and from the inoculated plants by using the protocol described by (3). RT-PCR was performed with the primer pairs WCIEN (5'ATG GTT TGG TGY ATY GAR AAT 3') (12) and PV1 (5' GAT TTA GGT GAC ACT ATA GTT TTT TTT TTT TTT TTT 3') (7), general primers for Potyvirus genus. 


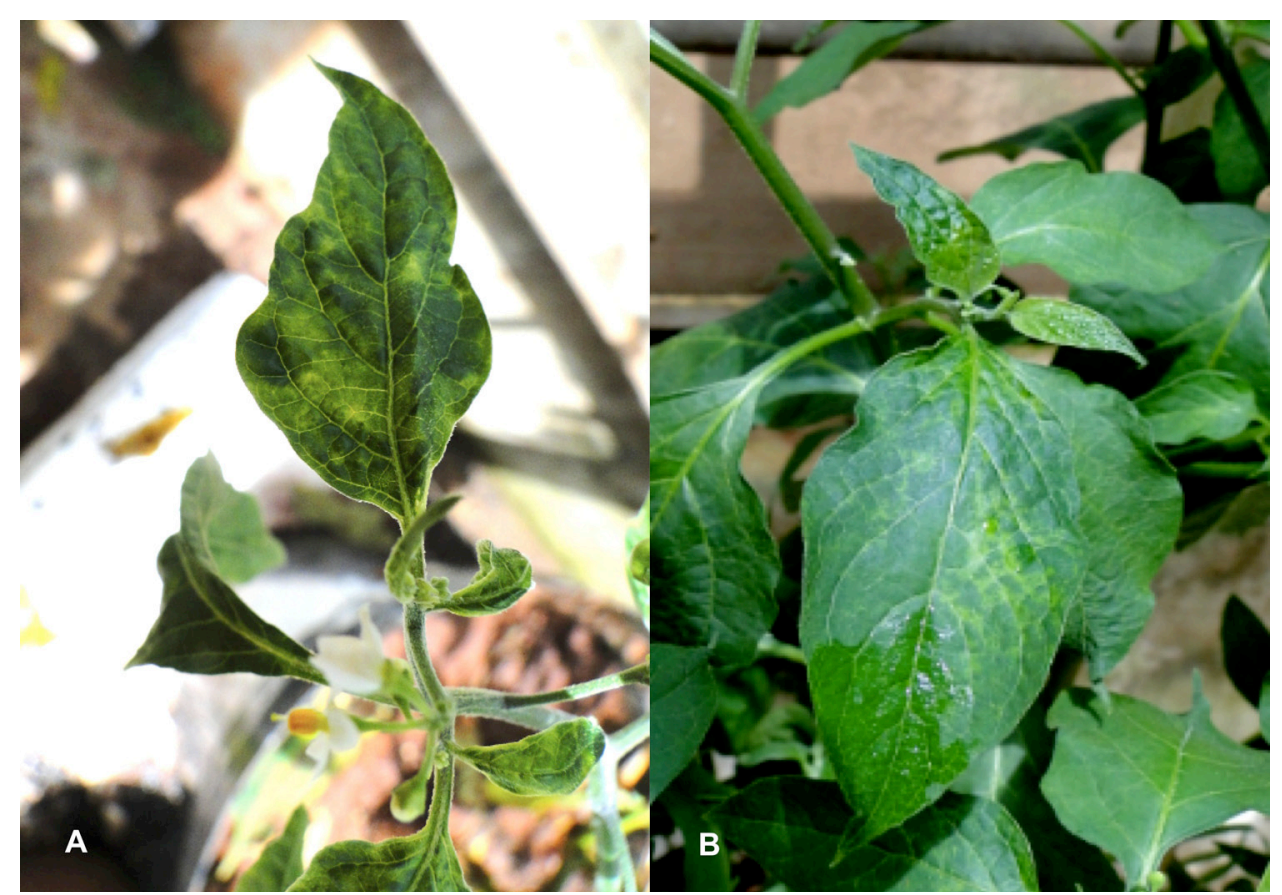

Figure 1. Mosaic symptoms and leaf distortion on Solanum americanum collected from the field: isolate 71d (A) and isolate 72d (B).

To detect CMV, the primer pairs 035-3 (5' GCC GTAAGT GGA TGG ACA A 3') and 038-8 (TAT GAT AAG AAR CTT GTT TCG CG 3') were employed (4) in a one-step reverse transcription (RT)-PCR assay, using the cycle $42^{\circ} \mathrm{C} / 30 \mathrm{~min}, 95^{\circ} \mathrm{C} / 2 \mathrm{~min}$ and 35 cycles of $94^{\circ} \mathrm{C} / 1$ $\min , 55^{\circ} \mathrm{C} / 2 \mathrm{~min}$ and $72^{\circ} \mathrm{C} / 2 \mathrm{~min}$, ending with $72^{\circ} \mathrm{C} / 5 \mathrm{~min}$.

For the potyvirus fragment, a nucleotide identity of $94 \%$ was observed with PVY (GenBank Accession No AJ439545.1). To amplify the complete coat protein of PVY, the primer pairs PepNib (5' GWTSGYYGMMTTGGATGATG 3') and PepUTR (5' AGTAGTACAGGAAAAGCC 3') were used as described by (11) and the sequence was compared with those deposited in GenBank by using the programs Blastn (http://www. ncbi.nlm.nih.gov/BlAST) and
Clustal W (http://www. ebi.ac.uk/Tools/clustalw/index.html). For the complete CP, a nucleotide sequence identity of $97 \%$ was observed with PVY (GenBank Accession No HQ594528.1) for sample 72d (GenBank Submission No 1602271). A mixed infection between PVY (GenBank Submission No. 1602256) and CMV (GenBank Submission No. 1602253) was observed for sample 71d and confirmed by the nucleotide identity of 99\% with PVY (GenBank Submission No. 1602256) and 96\% with CMV (GenBank Accession No. JN054635.1).

Both CMV and PVY found in S. americanum are closely related to isolates collected from tomato (Figure 2 and 3), even though this isolate has been collected from sweet pepper crops. The biological experiments confirmed that CMV and PVY from S. americanum can

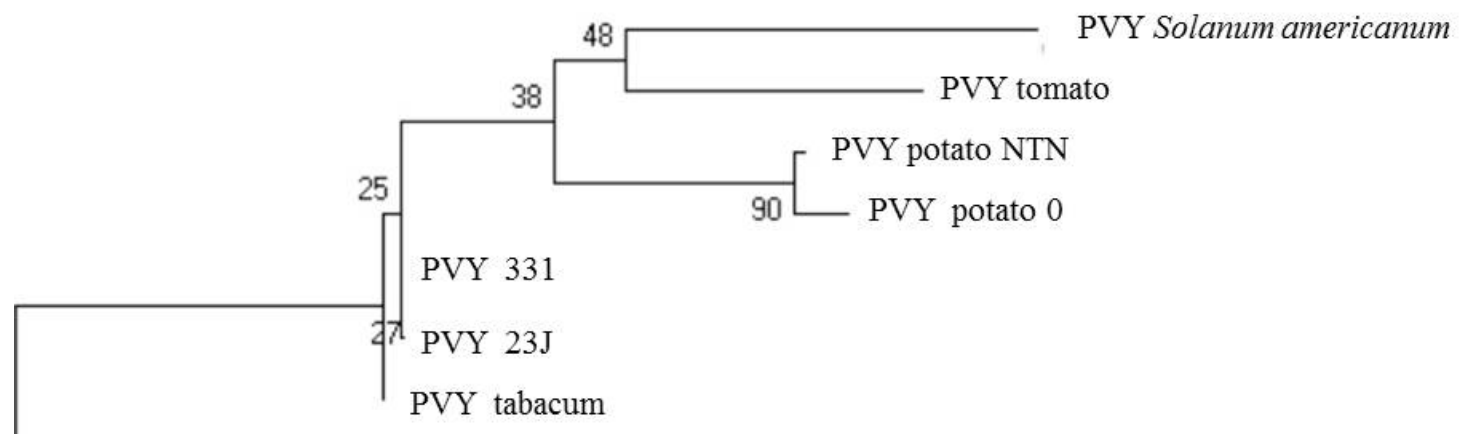

PVY ChiRSV

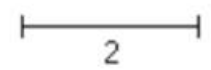

Figure 2. Phylogenetic tree obtained by the program Mega 5.0, bootstrap value 2000 replicates based on the nucleotide sequences of the CP coding region: PVY (Isolate 71d), PVY tomato (GenBank Access: JF 804783), PVY potato NTN (GenBank Access: JQ 924285), PVY potato 0 (GenBank Access: JQ 924285), PVY capsicum 331 (GenBank Access: HG 594528), PVY capsicum 23J (GenBank Access: 594529), PVY tabacum (GenBank Access: JN 711118). Outgroup Chilli ringspot virus (ChiRSV) (GenBank Access: DG 925438). 


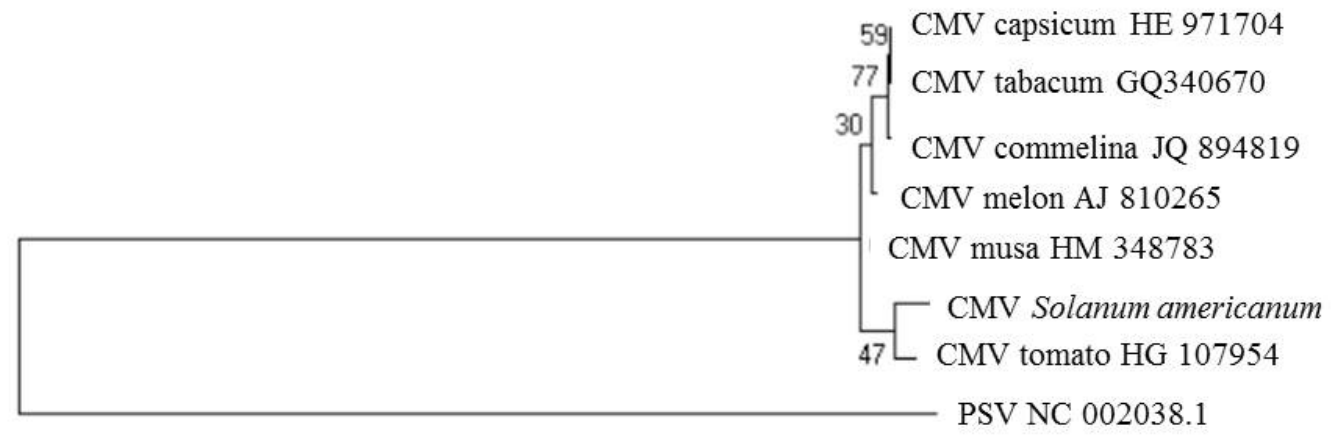

0.5

Figure 3 Phylogenetic tree obtained by the program Mega 5.0, bootstrap value 2000 replicates for the nucleotide coding region of the coat protein. CMV tomato (GenBank Access: HQ 107954), CMV melon (GenBank Access: AJ 810265), CMV capsicum (GenBank Access: HE 971704), CMV tabacum (GenBank Access: GQ 340670), CMV commelina (GenBank Access: JQ 894819), CMV musa (HM 348783). Outgroup Peanut stunt virus (PSV) (GenBank Access: NC 002038.1).

infect tomato and sweet pepper, and the latter host is a reservoir for these viruses during and between the sweet pepper crop seasons. $S$. americanum has been reported as an important reservoir for PVY in sweet pepper crops (9).

In São Paulo, PepYMV is the most frequently found potyvirus infecting sweet pepper, and infections by CMV and PVY (pathotype zero) can be observed occasionally (10). The increased use of resistant pepper material for PVY can explain the low incidence of PVY for this culture (10). Understanding the epidemiological role played by reservoir plants in the maintenance of viral diversity and in the acquisition of novel or enhanced virulence towards the cultivated host can help improve the management of the resistance gene.

In different cases, an emerging disease appears when a pathogen "jumps" to a host which was not infected by it (or no longer infecting) and adapts (or readapts) to it (2). RNA viruses, such as CMV and PVY, are likely to evolve in a reasonable experimental time because they have large population size, rapid replication rates and a high mutation rate (6).

Thus, periodically observing the incidence of Potyvirus and Cucumovirus in Solanaceae producing areas is important in order to verify a possible re-emergence of PVY and CMV, since these viruses are still present in the field, preferentially in weed species and not in cultivated plants. This result shows the high adaptability of important viruses in weeds such as black nightshade. We conclude that $S$. americanum is a natural reservoir for viruses and can act as a mixing vessel for different viruses affecting solanaceous in Brazil.

\section{REFERENCES}

1. Barbosa, J. C.; Barreto, S. S.; Inoue-Nagata, A. K.; Rezende, J. A. M. Characterization and Experimental Host Range of a Brazilian Tomato Isolate of Tomato severe rugose virus. Journal of Phytopathology, Berlin, n. 159, p.644-646, 2011.

2. Bedhomme, S.; Lafforgue, G.; Elena, S. F. Multihost experimental evolution of a plant RNA virus reveals local adaptation and host-specific mutations. Molecular Biology and Evolution, Oxford, v.29, p.1481-1492, 2012.

3. Bertheau, Y. D. ; Frechon, D. ; Toth, I. K. ; Hyman, L. J. DNA amplification by polymerase chain reaction (PCR). IN : Perombelon, M. C. M.; van der Wolff, J. M. Methods for the detection and quantification of Erwinia carotovora subsp. atroseptica on Potatoes. Scottish Crop Research Institute, Dundee, U.K., 1998.

4. Boari, A. J.; Maciel-Zambolim, E.; Carvalho, M. G.; Zerbini, F. M. Caracterização biológica e molecular de isolados do Cucumber mosaic virus provenientes de oito espécies vegetais. Fitopatologia Brasileira, Brasília, v.25, p.49-58, 2000.

5. Costa, A. S.; Carvalho, A. M. B.; Kitajima, E. W. Risca de tomateiro em São Paulo causada por estirpe do virus Y. Bragantia, Campinas, v.19, n.67, p.1111-1127, 1960.

6. Elena, S. F.; Sanjuan, R. Virus evolution: insights from an experimental approach. Annual Review of Ecology, Evolution and Systematics, Palo Alto CA, v.38, p.27-52, 2007.

7. Gibbs, A.; Mackenzie, A. A primer pair for amplifying part of the genome of all potyvirids by RT-PCR. Journal of Virological Methods, London, v.63, p.9-16, 1997.

8. Lima, M. G. A.; Martinelli, N. M.; Monteiro, R. C. Ocorrência de Frankliniella schultzei (TRYBOM) (THYSANOPTERA: THRIPIDAE) em plantas daninhas. Planta Daninha, Viçosa, v. 18, n. 2, p.367-372, 2000.

9. Moraes, C. A. P.; Chaves, A. L. R.; Eiras, M.; Galetti, S. R.; Colariccio, A. Solanum americanum uma fonte potencial de inoculo de Cucumber mosaic virus em plantação de pimentão. Revista Summa Phytopathologica. Botucatu, v.30, p.127-128, 2004.

10. Moura, M. F. Variabilidade de Potyvirus infectando Capsicum spp. no Estado de São Paulo. 2009. 89f. Dissertação (Mestrado em Agronomia - Proteção de plantas) Faculdade de Ciências Agronômicas, Universidade Estadual Paulista "Julio de Mesquita Filho", Botucatu.

11. Moura, M. F.; Mituti, T.; Marubayashi, J. M.; Gioria, R.; Kobori, R. F.; Pavan, M. A.; Silva, N.; Krause-Sakate, R. A classification of Pepper yellow mosaic virus isolates into pathotypes. European Journal of Plant Pathology, Wageningen, v.131, n.4, p. 549-552, 2011.

12. Pappu, S. S.; Brand, R.; Pappu, H. R.; Rybicky, E. P.; Gough, K. H. A polymerase chain reaction method adapted for selective amplification and cloning of 3' sequences of potyviral genomes: application to dasheen mosaic virus. Journal of Virological Methods, London, v.41, p.9-20, 1993. 